\title{
JOINT ASPECTS OF THE BOOK OF DEDE KORKUT AND CLASSICAL TURKISH LITERATURE
}

Abdullah AYDIN *

* Bingöl Üniversitesi

E-mail: divansiiri@hotmail.com

Copyright (C) 2016 Abdullah AYDIN. This is an open access article distributed under the Eurasian Academy of Sciences License, which permits unrestricted use, distribution, and reproduction in any medium, provided the original work is properly cited.

\begin{abstract}
The work under the name of Kitâb-1 Dedem Korkud Alâ Lisân-1 Tâife-i Oğuzân is widely titled as the Book of Dede Korkut. It is estimated that this work was put in writing at the late fifteenth century or the beginning of sixteenth century. The work with the stories which it contains, has enabled to reach today without the loss of many cultural elements of nomadic period of the Turks. Likewise, another tool that assumes the role of cultural trait is the classical Turkish literature which is the mirror of the great Ottoman geography. This literature which reflects the period of urbanization of the Turks and the average duration of which is six hundred years is also known by different names such as divan literature and old Turkish literature. The book of Dede Korkut and the classical Turkish literature which are penned with the same beliefs and values of the same nation undoubtedly show many points of similarity are the common aspects of reality. In this paper was investigated some jointly and heavily used motifs. When we look at the shared quotations we can see that the literature is a whole, though the utterance forms of different cultures which it carries; and it can not be divided into artificial nomenclature as folk literature, divan literature and so on. This work will contribute to the other studies which reveal joint aspects of folk literature and divan literature and also to support to increase the cultural common denominator between the literary opinions.
\end{abstract}

Keywords: Classical Turkish Literature, Dede Korkut, Divan, Folk Literature, Joint.

\section{DEDE KORKUT KITABI İLE KLASIKK TÜRK EDEBIYYTININ MÜŞTEREK YÖNLERI}

\section{ÖZET}

Kitâb-1 Dedem Korkud Alâ Lisân-1 Tâife-i Oğuzân başlığını taşıyan eser, yaygın olarak Dede Korkut Kitabı olarak isimlendirilmektedir. Eserin on beşinci yüzyılın sonları veya on altınc1 yüzyılının başlarında yazıya geçirildiği tahmin edilmektedir. Eser, içerdiği hikâyelerle Türklerin göçebelik dönemine ait pek çok kültür unsurunun kaybolmadan günümüze ulaşmasını sağlamıştır. Aynı şekilde kültür taşıyıcılığı rolünü üstlenen başka bir araç da büyük Osmanlı coğrafyasının aynası olan Klasik Türk Edebiyatıdır. Türklerin şehirleşme dönemini yansıtan ve ortalama altı yüzyıl süren bu Edebiyat da Divan Edebiyatı, Eski Türk Edebiyatı gibi değişik isimlerle anılmaktadır. Aynı milletin aynı inanç ve değer yargılarıyla kaleme alınan Dede Korkut Kitabı ile Klasik Türk Edebiyatının hiç şüphesiz pek çok noktada benzerlikler göstermesi, ortak yönlerinin olması bir gerçektir. Bu bildiride müşterek kullanılan ve kullanım yoğunluğu çok olan bazı motifler incelenmiştir. Paylaşılan örnek alıntılara bakıldığında; 
söyleyiş şekilleri farklı olsa da kültür taşıyıcısı olan edebiyatın bir bütün olduğu; Halk Edebiyat1, Divan Edebiyatı gibi suni adlandırmalarla bölünemeyeceği görülecektir. Bu bildiri Halk ve Divan Edebiyatının müşterek yönlerini ortaya koyan diğer çalışmalara katk1 sağlayacak, edebî görüşler arasındaki kültürel ortak paydanın artmasına destek olacaktır.

Anahtar Kelimeler: Classical Turkish Literature, Dede Korkut, Divan, Folk Literature, Joint.

\section{GIRIŞ}

Halk, Divân, Tekke

Duvar, kemer, kubbe

Yazımızın epigrafinde yer alan ve merhum Âmil Çelebioğlu'na ait olan ifade, edebiyatın şubelere ayrılsa bile- bir bütün olduğunu, aynı kültürün değişik tezahürlerinden teşekkül ettiğini ortaya koymaktadır. "Halk ve Divan Edebiyatının ortak ve benzer yönleri sanıldığından daha fazladır. Her iki edebiyatımız mahsulleri, aynı kültür ve inanç, aynı zevk ve fikir dünyasına, yani aynı cemiyete ait olmakla müşterek hususiyetlerin mevcudiyeti tabii olduğundan, dolayısıyla edebiyatımızın bir bütün olarak da ele alınması zaruridir" (Çelebioğlu 1998: 725). Buradan hareketle, Âmil Çelebioğlu'nun öğrencisi Cemâl Kurnaz, Halk ve Divan şiirinin müşterekleri üzerine araştırmalar yapmış ve Türk Edebiyatını yarısı sarı yarısı kırmızı olan güli ra'nâya benzetmiştir. "Türk kültürü, tarihi ve sanatı gibi edebiyatı da bir bütün" diyerek zihinlerdeki ikiliğin kaldırılması gerektiğini ifade eder (Kurnaz 1997: XIII). Bu ikilik halk nezdinde birinin el üstünde tutulması, diğerinin unutulması ve önyargılarla mümkün olduğu kadar kötülenmesi şeklinde ortaya çıkmıştır. Bu menfi tavır, önceki yerli ve yabancı kaynaklar Osmanlı Edebiyatı diye isimlendirdiği hâlde, 1924'te Ali Canip Yöntem'in Divan Edebiyatı diye isimlendirmesiyle (Akün 1994: 389) iyice ortaya çıkmış ve giderek artmıştır.

"Yeni sistemin köklenip filizlenmesi ve eski rejimin izlerinin elden geldiğince azaltılması amacıyla takip edilen kültür politikaları" (Şentürk 2004: XII) yüksek zümre edebiyatı, halktan kopuk, dili ağır gibi ifadelerin yaygınlaşmasına sebep olmuştur. Oysa "bu şiir tamamen yüksek eğitim görüp ilim ve irfan itibariyle kendini geliştirmiş kimselerin değil, aksine aynı zamanda okuma yazma bilmeyenlerin de şiiriydi” (Şentürk 2004: XIII). Nitekim yapılan çalışmalar, okuryazar olmayan şairlerin söyleyerek başkalarına yazdırdıkları güzel gazellerinin olduğunu ortaya koymuştur (Kurnaz ve Tatcı 2001).

Dede Korkut Kitabı'nı yayımlayan Muharrem Ergin, Fuat Köprülü'den 'Bütün Türk Edebiyatını terazinin bir gözüne, Dede Korkut'u öbür gözüne koysanız, yine Dede Korkut ağır basar." (Ergin 1995:5) şeklinde bir cümle paylaşmaktadır. Tamamen millî olan, konusunu millet hayatından alan ve içerisinde zengin kültürel unsurlar bulunduran Dede Korkut Kitabı Edebiyat tarihimiz açısından büyük önem taşımaktadır.

Dede Korkut, Kitâb-ı Dedem Korkud Alâ Lisân-ı Tâife-i Oğuzân başlı̆̆ını taşıyan, on beşinci yüzyılın sonları veya on altıncı yüzyılının başlarında yazıya geçirildiği tahmin edilen ve on iki hikâyeden müteşekkil eserin kahramanıdır. Hayatı hakkında anlatılanlarla efsanevi bir kişilik kazanmıştır (Gökyay 1994: 77). 
Dede Korkut Kitabı'nın Dresden'de ve Vatikan'da olmak üzere bilinen iki nüshası bulunmaktadır. Bu nüshalardan hazırlanan ilmî neşir 1964'te Muharrem Ergin (Ergin 1995: 10) ve 1973'te de Orhan Şaik Gökyay tarafından yayımlanmıştır (Gökyay 1994: 80). Ayrıca yurtdışında da yayımlanmış, değişik dillere çevrilmiştir.

Edebiyat tarihimiz açısından böylesine önemli bir eserin aynı kaynaktan beslenen ve aynı topluma hitap eden Klasik Türk Edebiyatıyla pek çok ortak unsur barındırması gayet tabiidir. Milletin maddî ve manevî birikimlerinden meydana gelen kültürel hazine, Divan şiirindeki aynı kullanım özellikleriyle Dede Korkut Kitabı'nda da görülmektedir. Çok sayıda olan bu müşterek noktalardan -yazımızın boyutları düşünülerek- yaygın olanlar örneklerle paylaşılacaktır.

\section{Dinî Konular}

\subsection{Tevhit}

Arapça olan tevhit kelimesi bir kılma, birleştirme, bir sayma anlamlarına gelmektedir (İsen ve Macit 1992: IX). Dinî 1stılah olarak ise Allah'ın varlığına ve birliğine inanmak, ona ortak koşmamaktır. "Edebiyatta tevhit ise; Allah (c.c.)'ın varlığını, birliğini ve yüceliğini bazen nesir, çoğu zaman da manzum olarak ele alıp işleyen parçalara verilen isimdir" (Canım 2010: 334).

Klasik Türk Edebiyatında müstakil bir eser olarak yer alan tevhitler, bazen diğer eserlerin giriş kısımlarında bulunmaktadır. Bu durum Dede Korkut Kitabı'nda da görülmektedir:

Yücelerden yücesin

Kimse bilmez niçesin

Aziz Tanr1

Sen anadan toğmadun

Sen atadan olmadun

Kimse rıkkın yimedün

Kimseye güç itmedün

Kamu yirde ahedsin

Sen Allahu samedsin

Âdeme sen tac urdun

Şeytana la'net kildun

Dede Korkut (Harmanc1 2012: 5)

Birdir O birliğine şek yok durur

Gerçi yanlış söyleyenler çok durur

Cümle ‘âlem yoğiken O var idi 
Yaradılmıştan ganî Cebbâr idi

\author{
Yoğiken var eyleyen çün $\mathrm{O}$ durur \\ Kudretinden cümleyi O oldurur
}

Süleyman Çelebi (D. 1350-1355/Ö. 1422?) (Pekolcay 1997: 48)

Süleyman Çelebi'nin Mevlid'inden alıntılanan ifadelerde de görüleceği üzere her iki metin de aynı inanç ikliminin ürünüdür.

\title{
1.2. Münacat/ Dua
}

Münacat Allah'â dua etme, yalvarma demektir. Edebî terim olarak içeriği Allah'a yakarış olan şiirlerdir (Kurnaz 1992: 1). Genellikle, şairlerin seçme şiirlerinden oluşan divanlarda tevhitlerden hemen sonra gelmektedir. Şiirlerin sonlarında şairin hem kendine hem de şiir sunduğu kişiye sağlık, ömür, afiyet dilekleriyle Allah'a yakardığı bölümdür. Kuran-1 Kerim'de Furkan suresinin yetmiş yedinci ayetinde "(Resûlüm!) De ki: (Kulluk ve) yalvarmanız olmasa Rabbim size ne diye değer versin?” denilmektedir (Özek 1998: 365). Kültürümüzde duanın etkisi kabul edilmiş ve genellikle insanın kendisi için değil de başkaları için dua etmesi tavsiye edilmiştir.

Dede Korkut Kitabı'nda dua kavramı çokça geçmektedir. Eserde “... büyük ziyafet ver, dilek dile, olur ki bir ağzı dualının hayır duası ile Tanrı bize topaç gibi çocuk verir” (Ergin 1995: 24) örneğinde olduğu gibi hikâye içlerinde duanın önemine vurgu yapılmaktadır. Ayrıca tüm hikâyeler duayla bitmektedir:

"Dua edeyim hanım: Yerli kara dağların yıkılmasın. Gölgeli koca ağacın kesilmesin. Ak sakallı babanın yeri cennet olsun. Oğul ile kardeşten ayırmasın. Ahir vaktinde arı imandan ayırmasın" (Ergin 1995: 89).

Dua, Klasik Türk Edebiyatında da önemli bir yer tutmaktadır. Hemen hemen tüm nazım türlerinin sonlarında dua bulunmaktadır:

Hemân Allâh ede ‘ömrünü mezîd

Bahş ede hayr ile 'izz-i câvîd

Ber-murâd olsun İlâhî her ân

Hayr ile yâ Rab o Hasân-1 zemân

Nûrî (D. 1758-1759/ Ö. 1815) (Aydın 2015a: 


\subsection{Hizır}

Hızır, Kurân-1 Kerîm'de Musa Peygamber ile macerası anlatılan, peygamber veya veli olduğu rivayet edilen kişidir. Arkadaşı İlyas ile beraber zorda kalan insanların yardımına koştuğuna inanılmaktadır (Pala 1995: 248).

Sana tâbi olan çekmez melâl ü mihnet-i âlem

Ne gam zulmât def'inden ana kim Hızr rehberdir

Fuzûlî (D. 1483/ Ö. 1556)

(Tökel 2000: 376).

Dede Korkut Kitabı'nda sadece bir hikâyede Hızır motifi bulunmaktadır. Burada Hızır, Babası tarafından okla vurulup yaralı hâlde terk edilen Boğaç’ın yardımına koşmaktadır. Başka eserlerde yaygın olan Hizır motifinin bu eserde sınırlı olmasının sebebi olarak Dede Korkut gösterilebilir (Köksel 2012: 83). Zira Dede Korkut, alperen edasıyla her hikâyede ortaya çıkmaktadır.

\subsection{Gömlek Motifi}

Klasik Türk Edebiyatında gömlek motifi denildiğinde Hz. Yusuf kıssası akla gelmektedir. Kardeşleri Yusuf'u bir kuyuya atarlar ve gömleğine kan bulaştırarak babaları Hz Yakup'a Yusuf'u bir kurdun yediğini söylerler (Tökel 2000: 306). Ağlamaktan gözleri kör olan Yakup, y1llar sonra Yusuf'un başka bir gömleğini gözlerine sürerek görmeye başlar. Kam Püre'nin Oğlu Bamsı Beyrek Destanı ile Yusuf Kıssası arasında pek çok müşterek nokta vardır (İçli 2013). Babasının Bamsı Beyrek'e yetki vermesinden rahatsız olan ve Banu Çiçek'le kendisi evlenmek isteyen Yaltacuk, kötü adam rolündedir. Bamsı Beyrek'in kendisinde bulunan gömleğini kana bulamış ve Bamsı öldü diyerek babasına götürmüştür. Bu hikâyede de üzüntüden babanın gözleri önce kör olur, bir zaman sonra Bamsı'ya ait mendilin sürülmesiyle görmeye başlar.

\section{2. İnsanla İlgili Konular}

\subsection{Medhiye}

Medih birinin iyiliğini söyleme, onu övme anlamlarına gelmektedir. Aynı kökten türeyen medhiye terimi ise; edebiyatımızda kaside nazım şeklinin bir bölümü (Mermer ve Koç Keskin 2005: 66) veya kendisine eser sunulan kişinin övüldüğü müstakil bir şiirdir. Medhiye, şairlerin genellikle herhangi bir istekte bulunacakları zaman sundukları şiirlerdir. Aynı durum Dede Korkut'ta da söz konusudur. Babasını esir bulunduğu yerden kurtarmaya gitmek için Bayındır Han'dan izin isteyen Yegenek, isteğini muhatabını methederek söylemektedir:

Atlas-ile yapılanda gök sayvanlu

Tavla tavla çekilende şahbaz atlu

Çağıruban dad virende bol çavuşlu 
Yaykanduğunda yağ dökilen bol ni'metlü

Kalmış yigit arhası

Beze miskin umud 1

Türkistanun diregi

Tülü kuşun yavrısı

Amit suyınun aslanı

Karaçuluğun kaplanı

Devletli han meded

Dede Korkut (Harmanc1 2012: 6)

Sultân-1 şark u garb şehenşâh-1 bahr u ber

Dârâ-yı dehr Şâh Süleymân-1 kâm-rân

O1 şeh-süvâr-1 memleket-i ‘adl ü dâd kim

Atı önince olsa revâ husrevân revân

Devründe kimse cevr-i sitem-gerden inlemez

Bî-şer' ider iderse eger çeng ü ney figân

Bâkî (D. 1526/ Ö. 1600) (Küçük 1994: 4)

\subsection{Beddua}

Türkçesi kargış olan beddua, duanın zıddı olup bir kişinin kötülüğü için Allah’a yalvarmayı ifade eder. Hoş karşılanmasa da kültürümüzde var olduğu bir gerçektir. Dede Korkut'ta da azımsanmayacak kadar beddua yer almaktadır:

Ala gözden ayırdun yigit meni

Tatlu candan ayırsun Kadir seni

Dede Korkut (Harmanc1 2012: 12)

Halk Edebiyatı ürünlerinde olduğu gibi divanlarda da bedduayla karşılaşmaktayız:

Sebep oldun ayırdın beni yârdan

Tîg-1 gazab sana yâr olsun rakib 
Kurtulma cihanda âh ile zârdan

Köhne dünyâ başına dar olsun rakib

Âş1k Ömer (D. 1621?/ Ö. 1707) (Çelepi 2005: 314)

Ömri oldukça belâdan kurtılup şâd olmasun

'Âkıbet ber-dâr olup rüsvâ-yı 'âm olsun [rakîb]

Halîlî (D. ?/ Ö. 1485) (Çakır 2006: 405)

\subsection{Kadın}

Dede Korkut Kitabı'nda kadın konusu, Klasik Türk Edebiyatında olduğu gibi çok yönlü işlenmemektedir. Dede Korkut henüz eserin girişinde kadınlara dair bir tasnif yapmakta; dolduran top, solduran sop gibi ifadelerle kadınlara dair müspet ve menfi görüşler sıralamaktadır. Kadınlara dair menfi düşünceler, bazı divan şairleri tarafından da dile getirilmektedir.

Edebiyatımızda kadın konusunun müspet manada işlendiği şiir örnekleri muhakkak daha çoktur. Sevgili rolünde olan kadının fizikî özellikleri yanında kişiliğine dair pek çok ifade kullanılmaktadır. Günümüzde türkülerde gördügümüz servi boylu, al yanaklı güzeller yüzyıllardır aynı özelliklerle yâd edilmektedir:

Berü gelgil başum bahtı, evüm tahtı

Evden çıkup yürüyende selvi boylum

Topuğunda sarmaşanda kara saçlum

Kurulı yaya benzer çatma kaşlum

Koşa badem sığmayan tar ağızlum

Güz almasına benzer al yanaklum

Kadınım, diregüm, dölüğüm

Dede Korkut (Kaplan 1951: 106)

Klasik Türk Edebiyatının temsilcilerinden olup sarayda yaşayan Kanunî Sultan Süleyman, aşağıya alıntılanan beyitlerinde sade ve anlaşılır Türkçesiyle -aynı Dede Korkut’ta görüldüğü gibi- seslenmektedir:

Göz kara vü kaş kara kirpik kara

Bana olmışdur belâ ender belâ

Bend-i zülfine dolaşdı çün gönül

Anlamazam dahi ayruk kurtula

Muhibbî (D. 1494/ Ö 1566) (Çabuk 1980: 48) 
Dede Korkut hikâyelerinin oluştuğu toplum göçebedir. Dolayısıyla hikâyelerde yerleşik düzenin şiiri olan Klasik Türk Edebiyatının kadın motifinden farklı özellikler görülmektedir. Kadın, bir aşk motifi değil kılıç kuşanan, güreş tutan, ata binen ve kahramanlıklar gösteren bir konumdadır.

\section{4. Çocuğun Önemi}

Türk Edebiyatında neslin devamı açısından çocuk sahibi olmanın önemine en fazla değinen eser biri Dede Korkut Kitabı'dır. Dirse Han oğlu Boğaç Han Destanı'nda oğlu olan ak otağa, kızı olan kızıl otağa, çocuğu olmayan kara otağa oturtulur. İkramlar oturduğu otağın rengine göre değişir. Dirse Han servi boylum diye hitap ettiği eşine çocuk konusunda kızmakta hatta onu dövmekle, öldürmekle tehdit etmektedir:

Han kııı yerimden kalkayım mı

Yakan ile boğazından tutayım mı

Kaba ökçemin altına atayım mı

Kara çelik öz kılıcımı elime alayım mı

Öz gövdenden başını keseyim mi

23)

Dede Korkut (Ergin 1995:

Evliliğe karşı menfî düşünceler ileri süren bazı divan şairleri de, ailede çocuğun önemine dikkat çekerek evlilik müessesesine sadece çocuk sahibi olmanın bir yolu olarak yaklaşmışlardır. Enderunlu Fâzıl'a göre; Allah, insan neslinin devam etmesini murat ettiği için kadınları güzel yaratmış, böylece erkekler de kadınlara meyletmiştir:

Ol sebep virdi hakîm-i kudret

Frrka-i cins-i zenâne zînet

Kıldı hatdan ruh-1 zîbâsını pâk

Mûydan eyledi a'zâsını pâk

Tâ ki meyl eyleye nefs-i gilmân

Münkarız olmaya nev'-i insân

Enderunlu Fâzil (D. 1756/ Ö. 1810) (Kazan 2008: 53)

Çocuk sahibi olmak, kültürümüzde bu denli önemli bir yer tutmaktadır. Aileler dualarla, adaklarla sahip oldukları çocuklarının üzerine titremekte, verdikleri değeri göstermek için onlara çok güzel ifadelerle seslenmektedir. Bu durum Dede Korkut’ta olduğu gibi özellikle de nasihatnamelerde görülmektedir: 
Oğul oğul ay oğul

Karşı yatan kara dağımın yükseği oğul

Güçlü belimin kuvveti canım oğul

Karanlıklı gözlerimin aydını oğul

Şafak vakti yerimden kalktığım senin için

Yağız al atımı yormuşum senin için

Ak giyimime kir eklendi senin için

Benim başım kurban olsun canım oğul senin için

Dede Korkut (Ergin 1995: 106)

Oldı zâtun senün iy nûr-1 basar

Zînet-i gülşen-i hestî-i peder

Salalı başuma zâtun sâye

Ben senünle bakaram dünyâya

Nâbî (D. 1642/ Ö. 1712) (Kaplan 2008:

179)

Hamdülillâh ki Hudâ-yı Mennân

Seni bu bendeye kıldı ihsân

Mihr-veş eyleyüp işrâk u zuhûr

Dil-i târîkümi kıldun pür-nûr

Vehbî (1720/ Ö. 1809) (Beyzadeoğlu 2004: 141)

Dede korkut Kitabı'nda çocuklara dair dikkat çeken diğer bir husus da çocuğa ad verilmesidir. Çocuğun büyüyüp bir kahramanlık göstermesi beklenmektedir. Yaptığı kahramanlığa göre Dede Korkut tarafından çocuğa bir ad verilmekte ve babasından ise beylik, yani bir sorumluluk verilmesi istenmektedir. Bu durum ile Klasik Türk Edebiyatındaki mahlas verilmesi arasında benzerlik bulunmaktadır. Kahramanlığın yerini şairlik yeteneği, Dede Korkut'un yerini de üstat bir şair almaktadır.

Bayındır Han'ın ak meydanında bu oğlan cenk etmiştir, bir boğa öldürmüş senin oğlun, adı Boğaç olsun, adını ben verdim yaşını Allah versin (Ergin 1995: 26).

Ey Tûba-yı heşt-behişt-i 'irfân

Ey Kevser-i tab' cûy-1 rıdvân 
Pîrân lisânlarından ‘'̇zzet

Mahlas sana virdi Baba Neş'et

Ola dü serâda nâmun 'İzzet

Allah vire dü cihân 'izzet

Neş'et (D. 1735/ Ö. 1807 )(Yıldırım 2006: 163)

\section{Gelenekle İlgili Konular}

\subsection{Yağma}

Yağma; zorla mal kapıp kaçma, çapul demektir. Hem hikâyelerde hem de divanlarda çok geçen bu anlam, günümüzde de yaygın olarak kullanılmaktadır. Eski kültürümüzde yağmanın müspet bir uygulama şekli vardır: Mal sahibinin her şeyini kendi rızasıyla yağmalatması. Sevinçli bir haber alan zengin kişinin, hanımını yanına alarak evinden veya dükkânından çıkması ve herkesin istediğini alabileceğini söylemesidir. Dede Korkut Kitabı'nda Kazan'ın kendi evini yağmalatması şöyle anlatılmaktadır:

Üç Ok, Boz Ok bir araya gelse Kazan evini yağmalatırdı. Kazan tekrar evini yağmalattı. ... Ne zaman Kazan evini yağmalatsa helâllisinin elini tutar, dışarı çıkard1, ondan sonra yağma ederlerdi (Ergin 1995: 205).

Zâtî, Letayif'inde kişinin kendi isteğiyle evini yağmalatmasına dair bir latife anlatmaktadır. "Keşfî, birgün sofi olduğunu söyleyerek dünyayı terk eder ve mallarını halka dağıtır. Zâtî, dağıtılan bu malların çoğunun haram yollarla kazanıldığını düşünerek helâl olan kısmından da kendine ister. Zâtî, böyle bir istekte bulunurken helâl kelimesini helâli şeklinde kullanarak hanımını kast eder" (Aydın 2013: 77).

Keşfî̀ didükleri kişi dünyâyı terk idüp

Bahş itdi cümle âleme mecmû'-1 mâlini

Kimi halâl ü kimi harâm idi anlarun

Bana tekellüf eyledi ol dem halâlini

Zâtî (D. 1471/Ö. 1547) (Çavuşoğlu, 1970:

5)

\subsection{Karalar Giymek}

Kültürümüzde yas tutmak; siyahlar giymek, karalar bağlamak sözleriyle dile getirilmektedir. Dede Korkut Kitabı'nda bir esaret veya ölüm haberi alındığında insanlar feryat figan etmekte, ak giysilerini çıkarıp karalar giymektedir: 
Babasına anasına haber oldu, apalaca yurduna feryat figan girdi, ak çıkardılar, kara giydiler. Kudretli oğuz Beyleri Beyrek’ten ümit kestiler (Ergin 1995: 71- 72).

Üzüntülü anların ifadesi olarak divan şiirinde de siyah renk kullanılmaktadır:

Firkât-i cânânla ciğger dağlarız,

Matem edip başa kara bağlarız

Leyl ü Nehâr yâr diyerek ağlarız,

Sel gibi hasretler ile çağlarız

Gulâmî (D. 4854/Ö. 1886) (Çelik ve Çelik 2010:116)

Bir gice ol gül-i ra'nâ tutılup mâh gibi

İrişe hâk oldı yiri mihr-i seher-gâh gibi

Matem içün n'ola giysem karalar âh gibi

Kanı ol gözlerimün nûrı Muhammed Şâh'um

Hüdâyî (D. ?/ Ö. 1584) (Demiralay 2007: 101)

\subsection{Yüzü Örtmek}

Dede Korkut Kitabı'nda kötü nazarlardan sakınmak maksadıyla dört yiğidin yüzlerini örterek gezdiği görülmektedir. Bunlar: Kan Turalı, Beyrek, Kara Çöğür ve oğlu Kırk Kınak’tır (Ergin 1995: 129). Divan şiirinde sevgilinin yüzüyle ilgili kurulan hayallerde de yüze peçe takmanın gerekliliği ifade edilmektedir. Dede Korkut'la aynı şekilde olmasa da yüzün örtülmesi gerektiği noktasında bir müştereklik bulunmaktadır.

Cemâlin mushâfın açma rakibe

Önünde kâfirin Kur'an yaraşmaz

Ahmed Paşa (D. 1426?/ Ö. 1496-1497) (Tarlan 1992: 172)

\subsection{Aşık Oyunu}

Koyun, keçi gibi hayvanların kemikleriyle oynanan aşık, Orta Asya'dan Anadolu'ya getirilmiş bir oyundur (Kaplan ve Poyraz 2010: 169). Bu geçiş döneminin ürünü sayılan Dede Korkut Kitabı'ndaki Boğaç Han Destanı'nda, içlerinde Boğaç'ın da bulunduğu çocuklar grubu aşık oyunu oynamaktadır (Ergin 1995: 25).

Aynı kültüre aynalık yapan divan şairleri de aşık oyununu şiirlerinde işlemiş̧lerdir:

Yimek içmek resmi oldı geldi gülmek oynamak

Aş1k oyunını teklîf eyledüm mihmânuma

2010: 169)

İshâk Çelebi (D. ?/ Ö. 1538) (Kaplan ve Poyraz 
Gel bezmüme idem seni dil mülkine sultân

Aşık oyunın oynayalum düşmeni terk it

Rahmî (D. 1510-1519/ Ö. 1567) (Erdoğan 2011: 277)

\section{Dünya İle İlgili Konular}

\subsection{Fena ve Fâni Dünya}

Klasik Türk Edebiyatı şairlerine göre dünya "âlem-i kevn ü fesâd" yani var olma ve aynı zamanda da bozulma yeridir (Sefercioğlu 2001:46). Dünya iyilerin yüzüne gülmez, âş1klara cevreder. Kimseye faydası olmayan aksine, fenalıklarla dolu bir yerdir. Divan şairlerinin bu yaklaşımı Dede Korkut Kitabı'nda da görülmektedir. Sonunda ölüm olan dünyanın kimseye kalmadığı birçok yerde vurgulanmaktadır:

Onlar da bu dünyaya geldi geçti

Kervan gibi kondu göçtü

Onları da ecel aldı yer gizledi

Fâni dünya yine kaldı

Gelimli gidimli dünya

Son ucu ölümlü dünya

Dede Korkut (Ergin 1995: 36)

Fenâ dünyâya aldanma

Bu mevcûdât kalur sanma

Bugüni yarına salma

Digil yâ hû vü yâ men hû

Fenâyî (D. 1574/ Ö. 1664) (Aydın 2004: 20)

Mâla mağrûr olma ey hâce ki bu dünyâ diyen

Sencileyin nice baykuş uçuran vîrânedir

Necâtî (D. 1443-1446/ Ö. 1509) (Durdu

2008: 53)

\subsection{Vatan Sevgisi}

Vatan sevgisi, hiç şüphesiz kültürümüzde önemli bir değer ifade etmektedir. "Vatan sevgisi imandandır (el-Aclûnî 2009: 308-309)." manasındaki mevzu hadis-i şerif, konuya İslâmî bir bakış açısı getirmektedir. Dede Korkut Kitabı'nda düşman tarafından talan edilmiş yurda dönen Kazan Bey'in yurduyla dertleştiği görülmektedir:

Kavim kabile benim ortak yurdum 
Yaban eşeği ile yabani geyiğe komşu yurdum

Seni düşman nereden dalamış güzel yurdum

Ak otağlar dikilince yurdu kalmış

İhtiyarcık anam oturunca yeri kalmış

Oğlum Uruz ok atınca hedef kalmış

Oğuz beyleri at sürünce meydan kalmış

Kara mutfak dikilince ocak kalmış

Dede Korkut (Ergin 1995: 42-43)

Dil-i dîvâneden eksilmedi şevkı ruhunun

Oldu rûşen bu ki imandan imiş hubb-1 vatan

Ahmed Paşa (D. 1426?/ Ö. 1496-1497) (Tarlan

1992: 133)

Dil şehr-i gamun terkini virmez senün i dost

Cânındaki îmân bigi hubbü'l-vatanı var

Aynî (D. ?/ Ö. 1490- 1494) (Mermer 1997:424)

\subsection{At}

Türk kültüründe, özellikle de göçebe Türkler arasında at önemli bir unsurdur. Göçebe hayatın izleri görülen Dede Korkut hikâyelerinde cinsi, rengi, gücü gibi özellikleriyle attan çokça bahsedilmektedir. Atlarıyla anılan yiğitler, atlarını hem yoldaş hem kardeş olarak görmektedir:

Açık açık meydana benzer senin alıncığın

İki gece 1ş1k saçan taşa benzer senin gözceğizin

İbrişime benzer senin yeleciğin

İki çift kardeşe benzer senin kulacığın

Eri muradına yetiştirir senin arkacığın

At demem sana kardeş derim kardeşimden daha iyi

Başıma iş geldi arkadaş derim arkadaşlarımdan daha iyi

Dede Korkut (Ergin 1995: 75)

Kahramanların yoldaşı olan at, Klasik Türk Edebiyatında da aynı rolüyle işlenmektedir. Öyle ki; rahşiye, esbiye, feresiyye, feres-nâme denilen ve atlardan bahseden bir edebî tür oluşmuştur (Aça vd 2011: 410).

Bir de Arslan Dorusudur ki gemin gördükçe

Kendidir aynı ile şîr-i ner-i silsile-hâ 
Urulur gerdenine anın içün altından

İki zencir ki zabt etmesi âsân ola tâ

Bir de Dağlar Delisidir ki şitâb etdikçe

Bir olur zelzeleden lerze-i kûh u deryâ

Sarsılır arz u semâ sanki kıyâmet koparur

Böyledir tünd şitâb eyledigince ammâ

Nef'̂̂ (D. 1572?/ Ö. 1635) (Kaya 2008: 354- 355)

\section{4. $\mathrm{Su}$}

Su, hayatın kaynağı olması sebebiyle şiir, şarkı, türkü, atasözü ve deyimlerde hep var olmuştur. Özellikle Fuzûlı̂’nin;

Saçma ey göz eşkden gönlümdeki odlara su

Kim bu denlü dutuşan odlara k1lmaz çâre su

Fuzûlî (D. 1483/ Ö. 1556) (İpekten 1996: 74)

matlalı Su Kasidesi'yle daha da önem arz etmiş; rahmet, bolluk, bereket olması yönüyle Hz. Peygamber ile arasında ilişki kurulmuştur.

Dede Korkut Kitabı'nda Salur Kazan -aynı Fuzûlî gibi- kutsiyet atfettiği suya hitap etmekte, ondan yurdunun durumu hakkında bilgi almaya çalışmaktadır:

Çă̆gl çağıl kayalardan çıkan su

Ağaç gemileri oynatan su

Hasan ile Hüseyin'in hasreti su

Bağ ve bostanın ziyneti su

Âyişe ile Fâtıma'nın bakışı su

Koç atların gelip içtiği su

Kızıl develerin gelip geçtiği su

Ak koyunların gelip çevresinde yattığı su

Yurdumun haberini biliyor musun söyle bana

Kara başım kurban olsun suyum sana

Dede Korkut (Ergin 1995: 43) 


\subsection{Kopuz}

Eski bir çalgı olan kopuz, Klasik Türk Edebiyatında gerek şekil gerekse sesi dolayısıyla işlenmekte, bazen de teşbih unsuru olarak şiirlerde yer almaktadır (Koç Keskin 2008).

Dede Korkut'un daima yanında taşıdığı kopuzu, onu elinde bağlamayla dolaşan âşıklar gibi tahayyül ettirmektedir. Hikâyelerde eğlence, güreş, dövüş ve savaş gibi duygu yoğunluğunun değişik olduğu ortamlarda kahramanlar kopuzlarını isteyerek, çalmaktadırlar. Aşağıdaki metinde kopuzun Osmanlıdaki mehter takımında olduğu gibi, savaşta askerin moral gücünü artırmak için kullanıldığı görülmektedir.

Kan Turalı sağına baktı kırk yiğidini ağlar gördü, soluna baktı öyle gördü. Der: Hey kırk eşim kırk arkadaşım, niye ağlıyorsunuz, kolca kopuzumu getirin övün beni dedi. Burada kırk yiğit kan Turalı’yı övmüşler (Ergin 1995: 129).

Raksa geldi bezm-i rezm içre ser-i a'dâ-yi dîn

Turreler itdükçe kûs-i heft-cûşı pür-sadâ

Sûr idi gûyâ nefîr-i mehterân bir nefh ile

Eyledi düşmenleri üftâde-i hâk-i fenâ

2004: 71)

Sâmî (D. ?/ Ö. 1734) (Kutlar

\subsection{Sayılar}

Sayılar, kültürümüzde matematiksel işlemlerden daha çok atasözleri, deyimler, destanlar, şiirler ve dinî içerikli eserlerde kullanılmaktadır. Bu sayılar genellikle ilk on sayı, 12 ve 40'tır (Yardımcı 2008; Küçük 2013). Sayılara yüklenen kültürel değerler büyük oranda Müslümanlık olmak üzere, Türklerin daha önceki dinî inanışlarından kaynaklanmaktadır.

Yazının boyutlarını aşacağından, diğer sayıları bırakarak burada sadece kırk sayısını ele almakta fayda vardır. "Müslümanlar arasında Hz. Muhammed'e 40 yaşında peygamberlik verilmesi, O’na ilk bağlananların 40 kişi olması, kişinin malının kırkta birini zekât olarak vermesinden dolayı kırk sayısı daha da önemli bir yere sahip olmuştur (Güvenç 2009: 90)". Burada, Muhammed isminin ilk harfi M(im)'in ebced hesabındaki değerinin kırk olduğu da hatırlanmalidir.

Dede Korkut Kitabı'nda sayılar dikkat çekecek derecede vurgulanmıştır. Örneğin Dirse Han Oğlu Boğaç Han Destanı'nda herhangi bir durumda Dirse Han kırk yiğidiyle, hanımı kırk ince kızıyla beraber gitmektedir. Yine Boğaç Han, kırk namertle savaşmaktadır. 
Sayılar, Klasik Türk Edebiyatında da çok yaygın olarak kullanılmaktadır. Rakamlar ile harfler arasında bağlantı kuran ebced sistemi, herhangi bir olay ya da durumun şiirselleştirilip tarih düşürülmesinde şairlere büyük imkânlar sağlamaktadır (Yakıt 2003).

Yahyâ n'ola olursa sözün inceden ince

Yârin beli vasfında kılı kırk yararsın

$$
\text { Yahyâ (D. ?/ Ö. 1582) (Bayram 2005: 51) }
$$

Geldi üçler târîh-i fevtin dedi merhûmmenin

Rûhunun ârâmgehi ola cinân-1 'âliyât

Nûrî (D. 1758-1759/ Ö. 1815) (Aydın 2015b: 198)

Yediler geldi târîhin dediler

Ola rûh-1 revânına rahmet

Nûrî (D. 1758-1759/ Ö. 1815) (Aydın 2015b: 206)

Günümüzde sadece Türkiye değil, Osmanlı bakiyesi topraklarda da kültürel bir öge olarak sayıların kullanımı devam etmektedir (Durbilmez 2011).

\section{Olağanüstü Motifler}

Dede korkut Kitabı'nda olağanüstü kahramanlık motifleri görülmektedir. Salur Kazan'ın hikâyesindeki Karacık Çoban olağanüstü güçlerle donatılmıştır. Bir taşla iki kâfir devirmekte, taşı bitince sapanıyla taş yerine koyun atmaktadır (Ergin 1995: 41). Burada tasvir edilen aşırı güç ve kuvvet, divan şairlerinin Hz. Ali'ye atfettiğine benzemektedir. Hayber Kalesi fethinde, Hz. Ali'nin çok büyük olan kale kapısını yerinden söktüğü ve kalkan gibi kullandığı rivayet edilmektedir.

Sensin ol Hayder ki dest-i mucizâtını görüp

Hükmine râm oldu Şam u Rum u Berber yâ Ali

Ol Ali sen kim şehâdet parmağın kallâb idüp

Kopdı yerden kuvvetinle bâb-1 Hayber yâ Ali

Hatâyî (D. 1487/ Ö. 1524)

(Üzüm 2004: 96)

Olağanüstü motifler arasında periler de görülmektedir. Tepe Göz'ün annesi bir peridir ve diğer perilerle pınar başına gelmişlerdir (Ergin 1995: 152). İnsanlara görünmeyen, göründüğünde perişan eden peri motifi divanlarda da görülmektedir:

Çeşm-i nâsa zerreçe görünmez iken bir perî

Tâli'ümdür ben seversem gün gibi rahşân ola

Rehâyî (D. ?/ Ö. 1698) (Yerdemir 2007: 118) 
Yok bu şehr içre senin vesf etdiğin dil-ber Nedîm

Bir perî-sûret görünmüş bir hayâl olmuş sana

Nedîm (D. 1681/ Ö. 1730) (Macit 1997: 274)

\section{Diğer}

Dede Korkut Kitabı ile ortalama altı yüz yıl süren ve Osmanlı kültürünün, medeniyetinin derin izlerini bünyesinde bulunduran Klasik Türk Edebiyat arasında bu yazıda kaydedilenlerden çok daha fazla müşterek nokta olduğu muhakkaktır. Bir derecelendirmeye tabi tutulsa birinci derece ortak unsurlar örneklerle paylaşılmıştır. Kullanım bakımından daha az olduğu için burada incelenmeyen ikinci derece ortak yönler ise şunlardır: Peygamber mucizelerine benzeyen olaylar, tarihin her döneminde görülen baba-oğul mücadelesi, namus kavramı, savaş öncesinde namaz kılınması, beşik kertmesi, mizah anlayışı, delilik motifi, nasihat edilmesi. Dede Korkut Kitabı dikkatlice okunduğunda burada zikrolunmayan üçüncü derece başka motiflerin de bulunabileceği ihtimal dâhilindedir.

\section{SONUÇ}

Dede Korkut Kitabı, içerdiği hikâyelerle Türklerin göçebelik dönemine ait pek çok kültür unsurunun kaybolmadan günümüze ulaşmasını sağlamıştır. Aynı şekilde kültür taşıyıcılığı rolünü üstlenen başka bir araç da büyük Osmanlı coğrafyasının aynası olan Klasik Türk Edebiyatıdır. Aynı milletin, aynı inanç ve değer yargılarıyla oluşturulmuş bu iki aracının hiç şüphesiz pek çok noktada benzerlikler göstermesi, ortak yönlerinin olması bir gerçektir. Buradan hareketle kullanım yoğunluğuna göre birinci derecede müşterek denilebilecek bazı motifler sınıflandırılarak incelenmiş̧ir. Hem Klasik Türk Edebiyatı alanında eserler vermiş şairlerinden hem de Dede Korkut'tan alıntılar yapılarak ortak unsurlar örneklenmiştir. Bu motifler söyleyiş şekilleri farklı olsa da, kültür taşıyıcısı olan edebiyatın bir bütün olduğu; halk, divan gibi suni adlandırmalarla bölünemeyeceği gerçeğini teyit etmiştir.

Türk Edebiyatı büyük oranda etkilendiği medeniyetle bağlantılı olarak İslamiyet Öncesi Türk Edebiyat1, İslamî Türk Edebiyat1, Batı Etkisinde Gelişen Türk Edebiyat1; Divan edebiyat1, Klasik Türk Edebiyatı, Halk Edebiyatı veya Yeni Türk Edebiyatı gibi adlandırmalarla sınıflandırılmıştır. Ancak yapılan araştırmalar -isimlendirme, söyleyiş, bakış açısı gibi farklılıklar taşımasına rağmen- tüm edebî metinlerin Türk gelenek ve göreneklerini dile getirdiğini, milletin değer yargılarını ve kültürel unsurlarını günümüze taşıdığını ortaya koymaktadır.

\section{REFERENCES}

- Aça, M. vd. (2011), Başlangıçtan Günümüze Türk Edebiyatında Tür ve Şekil Bilgisi, İstanbul. 
- $\quad$ Akün, Ö. F. (1994), “Divan Edebiyatı”, Türkiye Diyanet Vakfı İslâm Ansiklopedisi, C. IX, İstanbul, s. 389- 427.

- Aydın, A. (2004), Üsküdarlı Fenâyî Cennet Mehmet Efendi ve Dîvânı, İstanbul, Kaknüs Yayınları.

- Aydın, A. (2013), "Divan Şairlerinin Şiir Aracılığıyla Atışmaları”, Bingöl Üniversitesi Sosyal Bilimler Enstitüsü Dergisi, Güz, S. 6, Bingöl, s. 49-89.

- Aydın, A. (2015a), Hanyalı Nûrî ve Dîvânı, C. II, Berlin, Türkiye Âlim Kitapları Yayınevi.

- Aydın, A. (2015b), Hanyalı Nûrî ve Dîvânı, C. III, Berlin: Türkiye Âlim Kitapları Yayınevi.

- Bayram, Y. (2005), “16.Yüzyıldaki Bazı Divan Şairlerinin "Şair”e ve "İlham”a Dair Görüşleri', Türklük Bilimi Araştırmaları, Güz, S. 18, Niğde, s. 31-68.

- $\quad$ Beyzadeoğlu, S. A. (2004), Sünbülzâde Vehbî Lutfiyye, İstanbul: Millî Eğitim Bakanlığı Yayınları.

- Canım, R. (2010), Divan Edebiyatında Türler, Ankara: Grafiker Yayınları.

- Çabuk, V. (1980), Dîvân-1 Muhibbî (Kanunî Sultan Süleyman'ın Şiirleri), C. 1, İstanbul: Tercüman Gazetesi Yayınları.

- Çakır, M. (2006), "Bitlis Nâm Şehirden Bir Şâir: Halîlî Şiirleri ve Şâirliği Üzerine Değerlendirmeler", II. Van Gölü Havzası Sempozyumu, 04-07 Eylül 2006, Bitlis, s. 401420.

- Çavuşoğlu, M. (1970), Zâtî'nin Letâyifi, İstanbul: Edebiyat Fakültesi Yayınları.

- Çelebioğlu, Â. (1998), Eski Türk Edebiyatı Araştırmaları, İstanbul 1998: Millî Eğitim Bakanlı̆̆ı Yayınları.

- Çelepi, M. S. (2005), Âşık Ömer Divânı'nın Tahlîli, Süleyman Demirel Üniversitesi Sosyal Bilimler Enstitüsü Yüksek Lisans Tezi, Isparta.

- Çelik, İ. ve İ. Çelik (2010), Bir Sufi Şair: Abdülkâdir-i Gulâmî (1271-1303/1854-1886), Atatürk Üniversitesi Türkiyat Araştırmaları Enstitüsü Dergisi [TAED], S. 42, Erzurum, s. 97-118.

- Demiralay, M. (2007), Hüdâyî-i Kadîm (16. yy) ve Dîvân1- İnceleme- Tenkidli Metin, Süleyman Demirel Üniversitesi Sosyal Bilimler Enstitüsü Yüksek Lisans Tezi, Isparta.

- Durbilmez, B. (2011), “Batı Trakya Türk Halk Kültüründe Mitolojik Sayılar”, Zeitschrift für die Welt der Türken Journal of World of Turks, C.3, S. 1, Almanya, s. 77- 93.

- Durdu, M. (2008) Türk Edebiyatında Nasihat, Selçuk Üniversitesi Sosyal Bilimler Enstitüsü Yüksek Lisans Tezi, Konya.

- el-Aclûnî, İ. b. M. (2009), Keşfu'l-Hafâ ve Muzîlu'l-İlbâs, C. I, Beyrût: Dâru'l-Kutubi'lİlmiyye.

- Erdoğan, M. (2011), Bursalı Rahmî ve Dîvânı, İstanbul: Dergâh Yayınları.

- $\quad$ Ergin, M. (1995), Dede Korkut Kitabı, 17. Baskı, İstanbul: Boğazici Yayınları.

- Gökyay, O. Ş. (1994), "Dede Korkut”, Türkiye Diyanet Vakfı İslâm Ansiklopedisi, C. IX, İstanbul, s. 77-80. 
- Güvenç, A. Ö. (2009), “Kırk Sayısının Halk Edebiyatı Ürünlerinde Kullanımı Üzerine Bir İnceleme”, Atatürk Üniversitesi Türkiyat Araştırmaları Enstitüsü Dergisi, S. 41, Erzurum, s. 85- 97.

- Harmancı, M. (2012), "Dede Korkut Hikâyelerindeki Alkış ve Kargışlara İşlevsel Bir Yaklaşım”, Kocaeli Üniversitesi Sosyal Bilimler Enstitüsü Dergisi, S. 23, Kocaeli, s. 1-17.

- İçli, A. (2013), "Yusuf Kıssası ve Beyrek Hikâyesinde Gömlek Sembolizmi”, Uluslararası Sosyal Araştırmalar Dergisi, Bahar, C. 6, S. 26, Ordu, s. 267-274.

- İjekten, H. (1996), Fuzûlî Hayatı Sanatı Eserleri, Ankara: Akçağ Yayınları.

- İsen, M. ve M. Macit (1992), Divan Edebiyatında Tevhidler, Ankara: Türkiye Diyanet Vakfi Yayınları.

- Kaplan, M. (2008), Hayriyye-i Nâbî, Ankara: Atatürk Kültür Merkezi Yayınları.

- Kaplan, M. (1951). “Dede Korkut Kitabında Kadın”, Türkiyat Mecmuası, C. 9, İstanbul, s. 99- 112.

- Kaplan, Y. ve Y. Poyraz (2010), “Divan Şiirine Kaynaklık Etmesi Bakımından Oyunlar”, Uluslararası Sosyal Araştırmalar Dergisi -Klâsik Türk Edebiyatının Kaynakları Özel Sayısı Prof. Dr. Turgut KARABEY Armağan1-, C. 3, S. 5, Ordu, s. 151-175.

- Kaya, B. (2008), Divan Şiirinde At, Gazi Üniversitesi Sosyal Bilimler Enstitüsü Yüksek Lisans Tezi, Ankara.

- Kazan, Ş. (2008), "Klâsik Türk Şiirinde Solduran Sop ile Dolduran Toplar”, Turkish Studies International Periodical For The Languages, Literature and History of Turkish or Turkic, Volume 3/1, Winter, s. 34-58.

- Koç Keskin, N. (2008), "Dede Korkud'un Kopuzundan Osmanlı Şiirindeki Aşkın Kopuzuna", Turkish Studies International Periodical For the Languages, Literature and History of Turkish or Turkic, V. 3/1, Winter, s. 72-88.

- Köksel, B. (2012), “Dede Korkut Kitabı'nda Dinî-Mitolojik Yardımcı Kahraman Motifi”, Türkiye Sosyal Araştırmalar Dergisi, S: 161, Ankara, s. 73- 88.

- Kurnaz, C. (1992), Münâcât Antolojisi, Ankara: Türkiye Diyanet Vakfı Yayınları.

- Kurnaz, C. (1997), Türküden Gazele Halk ve Divan Şiirinin Müşterekleri Üzerine Bir Deneme, Ankara: Akçăg Yayınları.

- Kurnaz, C. ve M. Tatcı (2001), Ümmî Divan Şairleri ve Enverî Divanı, Ankara: Akçağ Yayınları.

- Kutlar, F. S. (2004), Arpaemîni-zâde Mustafa Sâmî, Divân, Ankara: Kalkan Matbaası.

- Küçük, S. (1994), Bâkî Dîvânı Tenkitli Basım, Ankara: Türk Dil Kurumu Yayınları.

- Küçük, M. A. (2013), “Türk Destanlarında "Sayı” Motifinin Dinî Yansımaları”, Gazi Türkiyat Türklük Bilimi ve Araştırmaları Dergisi, S. 13, Güz, Ankara, s. 91- 109.

- Macit, M. (1997), Nedîm Divânı, Ankara: Akçağ Yayınları.

- Mermer, A. (1997), Karamanlı Aynî ve Dîvânı, Ankara: Akçağ Yayınları.

- Mermer, A. ve N. Keskin Koç (2005), Eski Türk Edebiyatı Terimleri Sözlügüu, Ankara: Akçağ Yayınları. 
- Özek, A. vd. (1998), Kur’ân-1 Kerîm ve Açıklamalı Meâli, Ankara: Türkiye Diyanet Vakfı Yayınları.

- Pala, İ. (1995), Ansiklopedik Divan Şiiri Sözlüğü, Ankara: Akçağ Yayınları.

- Pekolcay, N. (1997), Süleyman Çelebi- Mevlid (Vesîletü’n-Necât), Ankara: Türkiye Diyanet Vakfı Yayınları.

- Sefercioğlu, M. N. (2001), Nevî Divânı’nın Tahlîli, Ankara: Akçağ Yayınları.

- Şentürk, A. A. (2004), Osmanlı Şiiri Antolojisi, İstanbul: Yapı Kredi Yayınları.

- Tarlan, A. N. (1992), Ahmet Paşa Divanı, Ankara: Akçağ Yayınları.

- Tökel, D. A. (2000), Divan Şiirinde Mitolojik Unsurlar- Şahıslar Mitolojisi, Ankara: Akçağ Yayınları.

- Üzüm, İ. (2004), "Şâh-1 Merdân Murtazâ Ali: Kültürel Alevî Kaynaklarına Göre Hz. Ali Tasavvuru”, İslâm Araştırmaları Dergisi, S. 11, İstanbul, s. 75- 100.

- Yakıt, İ. (2003), Türk İslâm Kültüründe Ebced Hesab1 ve Tarih Düşürme, İstanbul: Ötüken Yayınları.

- Yardımcı, M. (2008), “Geleneksel Kültürümüzde ve Âşıkların Dilinde Sayılar”, Edebiyat Tarihi Çerçevesinde Âşık Edebiyatı Araştırmaları, Ankara, s. 83-96.

- Yerdemir, F. (2007), Rehâyî Divanı İnceleme-Metin-Dizin, Gazi Üniveresitesi Sosyal Bilimler Enstitüsü Yüksek Lisans Tezi, Ankara.

- Yıldırım, A. (2006), Divan Edebiyatında Mahlas ve Mahlasnâmeler, Ankara: Akçağ Yayınları. 